\title{
Chemical Composition and Antimicrobial Activity of Essential Oils from the Aerial Parts of Pinus eldarica Grown in Northwestern Iran
}

\author{
Tayyebeh Ghaffari ${ }^{1}$, Hossein Samadi Kafil ${ }^{2} \oplus$, Solmaz Asnaashari ${ }^{3}$, Safar Farajnia ${ }^{2}$, \\ Abbas Delazar ${ }^{4}$, Su Cheol Baek ${ }^{5}$, Hamed Hamishehkar ${ }^{2, *}$ and Ki Hyun Kim ${ }^{5, *}$ (D) \\ 1 Drug Applied Research Center, Student Research Committee, Tabriz University of Medical Sciences, \\ Tabriz 51656-65811, Iran \\ 2 Drug Applied Research Center, Tabriz University of Medical Sciences, Tabriz 51656-65811, Iran \\ 3 Biotechnology Research Center, Tabriz University of Medical Sciences, Tabriz 51656-65811, Iran \\ 4 Research Center for Evidence based Medicine, Tabriz University of Medical Sciences, Tabriz 51656-65811, Iran \\ 5 School of Pharmacy, Sungkyunkwan University, Suwon 16419, Korea \\ * Correspondence: hamishehkarh@tbzmed.ac.ir (H.H.); khkim83@skku.edu (K.H.K.); Tel.: +98-41-336-3311 \\ (H.H.); +82-31-290-7700 (K.H.K.)
}

Received: 7 August 2019; Accepted: 30 August 2019; Published: 3 September 2019

\begin{abstract}
Pinus eldarica (Pinaceae), an evergreen plant, is distributed across the warm and dry climates of western Asia, including Asia Minor, the Middle East, and land surrounding the Caspian Sea. Essential oils (EOs) from different aerial parts of this tree have been used in traditional medicine. We aimed to investigate the chemical profile and antimicrobial activity of the EO from P. eldarica grown in northwestern Iran. EO from the needles, bark, and pollen were extracted with boiling water using a Clevenger apparatus at yield of $0.7-1.2 \mathrm{~cm}^{3} / 100 \mathrm{~g}$ of dry plant material. The main chemical components of the EO from the needles were D-germacrene $(18.17 \%)$, caryophyllene $(15.42 \%), \gamma$-terpinene $(12.96 \%)$, and $\beta$-pinene $(10.62 \%)$; those from the bark were limonene (16.99\%), caryophyllene oxide (13.22\%), and drimenol (13.2\%); and those from the pollen were $\alpha$-pinene (25.64\%) and limonene (19.94\%). In total, 83 constituents were characterized in the EOs, using gas chromatography mass spectrometry analysis; mainly, sesquiterpene hydrocarbons in needle EO and monoterpene hydrocarbons in pollen and bark EOs. $\beta$-Pinene, $\beta$-myrcene, limonene, and caryophyllene were identified in the EOs from all three plant parts. The antibacterial and antifungal properties of the EOs were examined: pollen EO exhibited antibacterial activity against Escherichia coli; bark EO inhibited the growth of Candida albicans and Staphylococcus aureus; and the needle EO inhibited the growth of $S$. aureus. Thus, the EOs from aerial parts of P. eldarica can benefit the EO industry and antibiotic development.
\end{abstract}

Keywords: Pinus eldarica; essential oil; chemical profile; antimicrobial activity; $\beta$-pinene; $\beta$-myrcene; caryophyllene; limonene

\section{Introduction}

Pinus eldarica, also known as the Tehran pine, is a coniferous tree of the family Pinaceae. The trees grow to a height of $12-15 \mathrm{~m}$ and have a brownish-gray or light gray bark. The needles are paired, medium green, and reach a length of $6-9 \mathrm{~cm}$. The cones may be either solitary or in pairs. P. eldarica is native to west Asia and is adapted to warm and dry climates. The trees grow on a wide variety of soil types and have been extensively planted in Iran [1,2]. Pines have been used in medicine and industry throughout human life. Pine needle essential oils (EOs) are used to add odors to products in the soap 
and perfume manufacturing industry. Previously, the analgesic, anti-inflammatory, and antiseptic effects of pine EOs have been reported [3].

P. eldarica has been used for the treatment of asthma [4]; moreover, it is useful in treating eczema and other skin wounds and irritations [5]. In previous studies, it has been shown that the EO from the bark of P. eldarica contains polyphenolic compounds, such as taxifolin and catechin, which have a wide range of pharmacological activities [6]. Owing to the important therapeutic applications of P. eldarica in traditional medicine, the composition of the EOs from the needles, fruits, and bark of P. eldarica grown in Isfahan and Iran has been investigated [2,7]. It was found that D-germacrene, $\beta$-caryophyllene, $\alpha$-pinene, and longifolene were the main components of the EOs of the needles, fruits, and bark of P. eldarica, respectively. The composition of resins and needle EOs from P. sylvestris, which is native to Europe and Asia, has also been assessed in previous studies $[3,8]$. The main constituents were $\delta$-3-carene, $\alpha$-pinene, $\delta$-cadinene, $\beta$-pinene, and camphene. The biological activities of the essential EOs of pines have been reported in different parts of the world [9]. The main components of pine extracts, such as $\alpha$-pinene and $\beta$-pinene, have displayed a wide spectrum of antimicrobial activities $[10,11]$. Previous studies have shown that pine extracts also have potential antifungal properties [12,13].

The composition and content of the EOs of P. eldarica may differ depending on the area where these pines are grown. To the best of our knowledge, this is the first study to analyze the EOs from the needles, bark, and pollen of the P. eldarica grown in northwestern Iran. The present study was designed to elucidate the chemical profile and antimicrobial activity of these EOs. With growing interest surrounding the use of EOs in the pharmaceutical industry, the results of this study may reveal a new horizon for the development of new pharmaceutical products.

\section{Results \& Discussion}

\subsection{Chemical Composition}

EOs were extracted from the aerial parts of P. eldarica via hydrodistillation. The yields of the EOs obtained were $1.2 \mathrm{~cm}^{3} / 100 \mathrm{~g}$ of dried needles, $0.7 \mathrm{~cm}^{3} / 100 \mathrm{~g}$ of dried pollen, and $0.9 \mathrm{~cm}^{3} / 100 \mathrm{~g}$ of dried bark (Table 1). These very low yields were consistent with those obtained in previous studies conducted on other species within the genus Pinus [14]. Therefore, it seems that this tree is an EO-poor plant.

Table 1. Yield of essential oils from aerial parts of Pinus eldarica.

\begin{tabular}{cc}
\hline Plant Materials & Yield of EO ${ }^{*}$ \\
\hline Needles & 1.2 \\
Pollen & 0.7 \\
Bark & 0.9 \\
\hline$*\left(\mathrm{~cm}^{3} / 100\right.$ g of dry plant material $)$.
\end{tabular}

The chemical compositions of the EOs from the needles, bark, and pollen of $P$. eldarica were analyzed using gas chromatography mass spectrometry (GC/MS) and are shown in Table 2 (The Gas chromatogram, condition and method are showed in the Supplementary Materials). The experimental retention indices (RI) of the chemicals in non-polar column and their percentage peak areas are also shown. The differences between the EOs of the needles, bark, and pollen were studied, and the main components of the EOs were identified. Fifty-eight constituents representing $99.98 \%$ of the needle EO, 11 components representing $99.94 \%$ of the pollen EO, and 33 components representing $99.79 \%$ of the bark EO were identified (Table 2). The main fraction of the EO derived from the dried needles was found to consist of sesquiterpene hydrocarbons ( $49.25 \%$ of the EO), which is in agreement with the results of previous studies [2,15]. Monoterpene hydrocarbons $(32.91 \%$ of the EO) made up the main fraction of the EO derived from dried bark; this was also found in a previously reported study [7]. In the pollen EO, monoterpene hydrocarbons (61.44\% of the EO) made up the main fraction, which has not been reported previously. The EOs of the three different aerial parts of P. eldarica were mostly 
composed of hydrocarbon compounds (Figure 1); caryophyllene, limonene, caryophyllene oxide, $\alpha$-pinene, and $\beta$-pinene were identified in all parts.

Table 2. The results of gas chromatography mass spectrometry (GC/MS) analysis of the chemical composition of essential oils obtained from the aerial parts of Pinus eldarica using hydrodistillation.

\begin{tabular}{|c|c|c|c|c|c|}
\hline \multirow[b]{2}{*}{ No. } & \multirow[b]{2}{*}{ Component $^{a}$} & \multicolumn{2}{|c|}{ Needles Bark } & \multicolumn{2}{|l|}{ Pollen } \\
\hline & & & ontent, & & $\mathbf{R I}^{\mathrm{b}}$ \\
\hline 1 & $\mathrm{n}$-Hentriacontane & 0.59 & - & - & 472 \\
\hline 2 & $\alpha$-Pinene & $t$ & - & 25.64 & 928 \\
\hline 3 & Camphene & 2.95 & 1.87 & - & 940 \\
\hline 4 & Verbenene & - & 1 & - & 949 \\
\hline 5 & $\beta$-Pinene & 10.62 & 2.82 & 3.12 & 967 \\
\hline 6 & $\beta$-Myrcene & 2.85 & 1.35 & 4.34 & 981 \\
\hline 7 & $\alpha$-Phellandrene & $\mathrm{t}$ & - & - & 994 \\
\hline 8 & Carene & 0.12 & - & 2.98 & 1017 \\
\hline 9 & $\beta$-Phellandrene & 0.2 & - & - & 1019 \\
\hline 10 & Limonene & 4.79 & 16.99 & 19.94 & 1020 \\
\hline 11 & Cis-Ocimene & 0.11 & - & - & 1025 \\
\hline 12 & $\beta$-Ocimene & 2.07 & - & - & 1036 \\
\hline 13 & $\gamma$-Terpinene & 12.96 & - & - & 1047 \\
\hline 14 & $\alpha$-Terpinolene & 0.23 & - & - & 1063 \\
\hline 15 & $\alpha$-Pinene oxide & - & 0.62 & - & 1065 \\
\hline 16 & Linalool & $\mathrm{t}$ & 0.85 & - & 1082 \\
\hline 17 & $\alpha$-Campholenal & $\mathrm{t}$ & - & - & 1097 \\
\hline 18 & $\alpha$-Campholene aldehyde & - & 1.72 & - & 1119 \\
\hline 19 & Verbenol & - & 2.46 & 5.42 & 1132 \\
\hline 20 & Pinocarvone & - & 1.15 & - & 1145 \\
\hline 21 & Myrtenal & - & 1.65 & - & 1166 \\
\hline 22 & $\alpha$-Phellandren-8-ol & - & 2.22 & - & 1167 \\
\hline 23 & Myrtenol & - & 1.71 & - & 1182 \\
\hline 24 & T-Carveol & - & 1.28 & - & 1204 \\
\hline 25 & Carvone & - & 1.17 & - & 1220 \\
\hline 26 & 2-Cyclopropylidene-1,7,7-trimethylbicyclo[2.2.1]heptane & 0.15 & - & - & 1254 \\
\hline 27 & Bornyl acetate & 3.09 & - & - & 1264 \\
\hline 28 & Thymol & $\mathrm{t}$ & - & - & 1270 \\
\hline 29 & $\alpha$-Terpinyl acetate & 1.68 & - & - & 1338 \\
\hline 30 & Neryl acetate & 0.16 & - & - & 1343 \\
\hline 31 & $\alpha$-Cubebene & 0.25 & - & - & 1360 \\
\hline 32 & $\alpha$-Copaene & 0.49 & - & - & 1387 \\
\hline 33 & Longifolene & - & 3.44 & 11.66 & 1393 \\
\hline 34 & $\beta$-Elemene & 0.38 & - & - & 1398 \\
\hline 35 & $\beta$-Cubebene & 0.82 & - & - & 1420 \\
\hline 36 & Caryophyllene & 15.42 & 9.43 & 3.52 & 1426 \\
\hline 37 & Aromadendrene & 0.23 & - & - & 1440 \\
\hline 38 & $\alpha$-Caryophyllene & 3.36 & - & - & 1454 \\
\hline 39 & $\alpha$-Humulene & - & 2.26 & - & 1463 \\
\hline 40 & $\alpha$-Amorphene & 0.81 & - & - & 1466 \\
\hline 41 & D-Germacrene & 18.17 & 0.93 & - & 1473 \\
\hline 42 & Valencene & 0.51 & - & - & 1486 \\
\hline 43 & Tridecanal & 0.23 & - & - & 1489 \\
\hline 44 & $\gamma$-Muurolene & 2.07 & - & - & 1501 \\
\hline 45 & $\alpha$-Cadinene & 0.13 & - & - & 1522 \\
\hline 46 & $\delta$-Cadinene & 2.42 & - & - & 1522 \\
\hline 47 & $\gamma$-Cadinene & 0.93 & - & - & 1525 \\
\hline 48 & $\alpha$-Muurolene & 0.73 & - & - & 1537 \\
\hline 49 & Epiglobulol & 0.16 & - & - & 1548 \\
\hline
\end{tabular}


Table 2. Cont.

\begin{tabular}{|c|c|c|c|c|c|}
\hline \multirow[b]{2}{*}{ No. } & \multirow[b]{2}{*}{ Component $^{\mathrm{a}}$} & \multicolumn{3}{|c|}{ Needles Bark Pollen } & \multirow[b]{2}{*}{$\mathrm{RI}^{\mathrm{b}}$} \\
\hline & & \multicolumn{3}{|c|}{ Content, \% } & \\
\hline 50 & Lauric acid & 0.34 & - & - & 1552 \\
\hline 51 & Isopatchoulane & 0.15 & - & - & 1552 \\
\hline 52 & Spathulenol & 0.91 & - & - & 1570 \\
\hline 53 & 4(14)-Salvialen-1-one & 0.34 & - & - & 1580 \\
\hline 54 & Cedrol & 0.33 & - & - & 1585 \\
\hline 55 & Caryophyllene oxide & 1.03 & 13.22 & 12.21 & 1595 \\
\hline 56 & Humulane-1,6-dien-3-ol & - & 0.88 & - & 1619 \\
\hline 57 & $\gamma$-Eudesmol & - & 0.62 & - & 1624 \\
\hline 58 & $\alpha$-Cadinol & 0.51 & - & - & 1630 \\
\hline 59 & Viridiflorol & 0.25 & - & - & 1636 \\
\hline 60 & Cadalene & 0.36 & - & - & 1641 \\
\hline 61 & Widdrene & 0.15 & - & - & 1644 \\
\hline 62 & Aromadendrene oxide & 0.63 & - & - & 1650 \\
\hline 63 & Pinocarveol & - & 2.82 & - & 1654 \\
\hline 64 & Isospathulenol & 0.12 & - & - & 1667 \\
\hline 65 & Tumerone & 1.76 & - & - & 1680 \\
\hline 66 & 6-Isopropenyl-4,8a-dimethyl-1,2,3,5,6,7,8,8a-octahydro-naphthalen-2-ol & 0.61 & - & - & 1690 \\
\hline 67 & 1,5-Epoxysalvial-4(14)-ene & 0.27 & - & - & 1945 \\
\hline 68 & 18-Norabieta-8,11,13-triene & - & 0.73 & - & 1969 \\
\hline 69 & Phenethyl isovalerate & - & 0.71 & - & 1986 \\
\hline 70 & Palmitinic acid & 0.97 & - & - & 2001 \\
\hline 71 & Humulene oxide & - & 1.61 & - & 2038 \\
\hline 72 & 13(16),14-Labdien-8-ol & - & 1.51 & - & 2120 \\
\hline 73 & Hexahydrofarnesyl acetone & 0.45 & 1.6 & - & 2131 \\
\hline 74 & Linalyl anthranilate & 0.4 & - & - & 2157 \\
\hline 75 & Manoyl oxide & - & 1.37 & 7.32 & 2376 \\
\hline 76 & Drimenol & - & 13.2 & - & 2494 \\
\hline 77 & $\alpha$-Campholenic aldehyde & $\mathrm{t}$ & & - & - \\
\hline 78 & Pinocarveylacetate & 0.18 & & - & - \\
\hline 79 & 3-Ethyl-3-hydroxyandrostan-17-one & 0.23 & & - & - \\
\hline 80 & tricyclo[4.3.0.07,9]nonane, $2,2,5,5,8,8$-hexamethyl & - & 1.02 & - & - \\
\hline 81 & Acetic acid, bornyl ester & - & 4.96 & - & - \\
\hline 82 & Isopimaric acid & - & 0.62 & - & - \\
\hline \multirow[t]{7}{*}{83} & Acetic acid, 1,7,7-trimethyl-bicyclo[2.2.1]hept-2-yl ester & - & - & 3.79 & - \\
\hline & Total & 99.98 & 99.79 & 99.94 & \\
\hline & Monoterpene hydrocarbons & 37.572 & 32.91 & 61.44 & \\
\hline & Oxygenated monoterpenes & 0.22 & 7.92 & & \\
\hline & Sesquiterpene hydrocarbons & 49.25 & 17.08 & 15.18 & \\
\hline & Oxygenated sesquiterpenes & 5.05 & 28.65 & 12.21 & \\
\hline & Diterpenoids & 0.23 & 4.23 & 7.32 & \\
\hline
\end{tabular}

a Compounds listed in order of elution from a DB-1 column; ${ }^{b}$ RI-retention index on non-polar column; $\mathrm{t}=$ trace $(<0.1 \%)$.

The main constituents of the needle EO were the sesquiterpene hydrocarbons D-germacrene $(18.17 \%)$ and caryophyllene $(15.42 \%)$ and the monoterpene hydrocarbons $\beta$-pinene $(10.62 \%)$ and $\gamma$-terpinene (12.96\%). The most abundant compound, D-germacrene, has been known to exert cytotoxic activity against cancer cell lines, fungicidal activity, and antibacterial properties against both gram-positive and gram-negative bacteria $[16,17]$. In a previous study, the main constituents of the P. eldarica needle EO were determined to be D-germacrene and $\beta$-caryophyllene [15]. This is consistent with the results of our study.

Among the monoterpene hydrocarbons that were found in needle EO, $\gamma$-terpinene (12.96\%) and $\beta$-pinene $(10.62 \%)$ were the most abundant. It has been reported that $\gamma$-terpinene possesses potent antioxidant and anti-inflammatory activity. Treatment with $\gamma$-terpinene has been shown to reduce inflammatory parameters, such as edema and cytokine production [18]. In a previous study, $\alpha$-pinene and $\beta$-pinene were determined to be the main compounds in P. eldarica [2]. Moreover, $\alpha$-pinene $(0.1-30.8 \%)$ and $\delta-3$-carene $(1.0-25.5 \%)$ were found to be the major components of the Lithuanian P. sylvestris needle EO [19]. It can hence be concluded that $\gamma$-terpinene has not been found in high amounts in other pines in previous studies. According to previous studies, even EOs from plants of the same species can differ in their composition according to the geographical location and age of the plant $[20,21]$. 
<smiles>CC1=CCC2C(C)(C)CCCC2(C)C1CO</smiles>

Drimenol<smiles>C=C1CC[C@H]2O[C@H]2CC[C@@H]2[C@@H]1CC2(C)C</smiles>

Caryophyllene oxide<smiles>C=C1C=C[C@@H](C(C)C)CCC(C)=CCC1</smiles>

D-Germacrene<smiles>C=C1CC/C=C(/C)CC[C@H]2[C@@H]1CC2(C)C</smiles>

Caryophyllene<smiles>C=C(C)C1CC=C(C)CC1</smiles>

Limonene

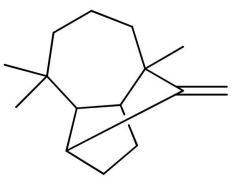

Longifolene

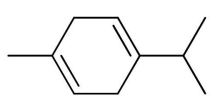

$\gamma$-Terpinene<smiles>C=CC(=C)CCC=C(C)C</smiles>

$\beta$-Myrcene

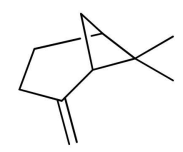

$\beta$-Pinene<smiles>CC1=CCC2CC1C2(C)C</smiles>

$\alpha$-Pinene

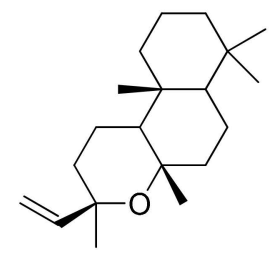

Manoyl oxide

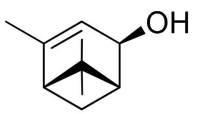

Verbenol

Figure 1. Some chemical components of essential oils obtained from the aerial parts of Pinus eldarica using hydrodistillation.

In the present study, in the pollen EO, $\alpha$-pinene (25.64\%) and limonene (19.94\%) were the most abundant compounds (Table 2). Pharmacological studies have suggested that low exposure to $\alpha$-pinene leads to anti-inflammatory activity via the suppression of mitogen-activated protein kinases (MAPKs) [22]. It has also been shown that $\alpha$-pinene has potential anti-osteoarthritic [23], antimicrobial [24], antiulcerogenic, and gastroprotective properties [25]. According to the results of the analysis of the bark EO, there was a high proportion of the monoterpene hydrocarbon limonene $(16.99 \%)$; moreover, oxygenated sesquiterpenes, such as caryophyllene oxide (13.22\%) and drimenol $(13.2 \%)$, were the next most abundant components. Limonene has been reported to possess potent antioxidant and anti-inflammatory properties [26] and inhibit the growth of cancer cells by interfering with the action of $G$ proteins involved in cell signaling pathways [27]. Caryophyllene oxide, an oxygenated terpenoid has been shown to exert significant antifungal [28] and anticancer activities via the suppression of cellular growth and induction of apoptosis [29]. In a previous study of the bark of P. eldarica from Isfahan and Iran, $\alpha$-pinene and caryophyllene oxide were the main constituents of the EO [7]. This result differed from that of the current study, possibly due to difference in the area the studied pines were grown. A classification of the samples based on structure type of EOs obtained from different aerial parts of P. eldarica is summarized in Figure 2. A large number of sesquiterpene hydrocarbons $(49.25 \%)$, monoterpene hydrocarbons $(37.57 \%)$, and oxygenated sesquiterpenes $(5.05 \%)$ were detected in the needle EO in this study, whereas the content of diterpenoids was significantly lower $(0.23 \%)$. The pollen and bark EO had a large abundance of monoterpene hydrocarbons ( $61.44 \%$ and $32.91 \%$, respectively). Considering all these data together has shown that there is quantitative variation between species and 
between different aerial parts of Pinus. This information could be valuable for the chemotaxonomic study of Pinus species.

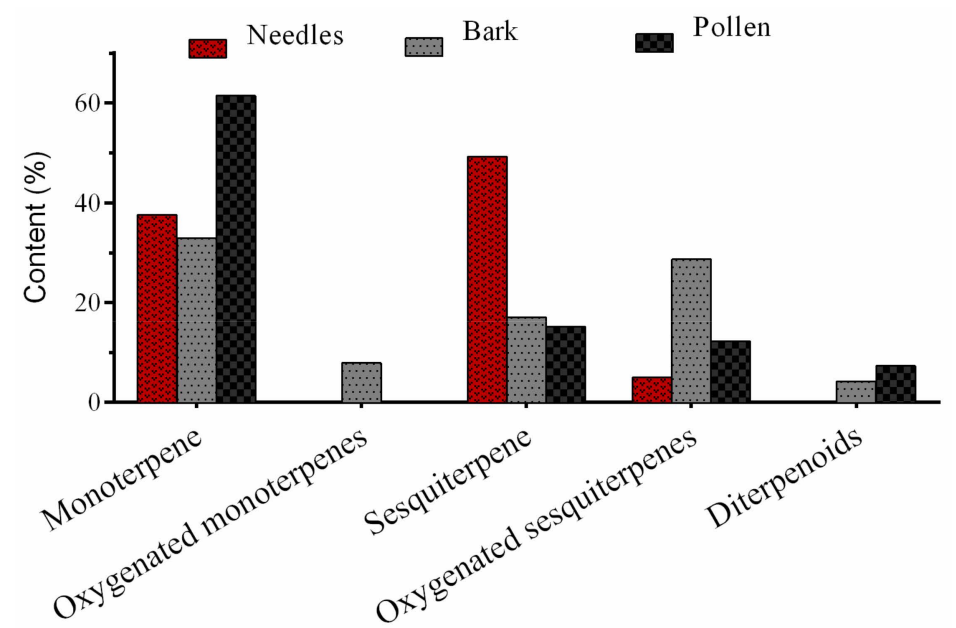

Figure 2. Chemical groups identified in the essential oils obtained from different aerial parts of Pinus eldarica.

\subsection{Antimicrobial Activity}

Recently, the antibiotic-resistant bacterial pathogens are increasing and resulting in a reduction in the efficiency of clinical treatments. Staphylococcus aureus and Escherichia coli have a high ability to become resistant to antibiotics. Latest reports of vancomycin-resistant $S$. aureus have shown that effective antibiotics against the organism may not be readily available for a long time [30]. It was demonstrated that $71.6 \%$ of E. coli strains isolated from children's stool and water samples in South Africa were multi-antibiotic resistant [31]. Several studies have focused on natural plant products with potent anticancer, antibacterial, antifungal, and antioxidant effects, and the efficacy of EOs have been emphasized [32-34]. According to our study, the EOs of P. eldarica contain monoterpene hydrocarbons, sesquiterpene hydrocarbons, and oxygenated hydrocarbons. In this study, the antibacterial and antifungal properties of the EOs of P. eldarica were examined. The results of the antimicrobial assay are presented in Table 3. Both needle and bark EOs displayed antibacterial activity against S. aureus (ATCC 29213) and pollen EO exhibited a bactericidal effect against E. coli (ATCC 25922). Candida albicans (ATCC 10231) was most sensitive to the bark EO, with a minimum inhibitory concentration (MIC) value of $125 \mu \mathrm{g} / \mathrm{mL}$. These EOs of P. eldarica contain major compounds, such as $\alpha$-pinene, germacrene, caryophyllene, and limonene, which have been reported to display antimicrobial activity against important pathogens. Rivas da Silva et al. [35] tested the biological activities of $\alpha$-pinene and $\beta$-pinene enantiomers against C. albicans, Cryptococcus neoformans $\mathrm{T}_{1}-444$ Serotype A, Rhizopus oryzae UCP1506, and $S$. aureus using the MIC and the minimal microbicidal concentration (MMC). They reported that the (+)-enantiomers showed high antifungal activity and that the synergistic effects of these compounds combined with microbicides reduced the MIC of the combined materials [35]. In the similar study performed by Scalas et al. [36], the EO of P. sylvestris and $\alpha$-pinene displayed good inhibitory activities against $C$. neoformans. In addition, combination of itraconazole with the EO of P. sylvestris showed a good synergistic action against $C$. neoformans. The EO of Liquidambar styraciflua leaf, which includes $\alpha$-pinene as its major compound, also showed a good synergistic effect with tetracycline and ciprofloxacin against Bacillus subtilis (ATCC 6633) [37]. In the present study, EO of pollen was rich in $\alpha$-pinene $(25.64 \%)$ and exhibited moderate antibacterial activity against $E$. coli with MIC level of $225 \mu \mathrm{g} / \mathrm{mL}$. Recently, one study reported the moderate antifungal activity of Thimus algeriensis EO against C. glabrata (ATCC22553) and C. albicans and a total of 29 compounds were identified in the EO of T. algeriensis, with $\alpha$-terpinyl acetate $(47.4 \%)$, neryl acetate $(9.6 \%)$, and $\alpha$-pinene $(6.8 \%)$ as the major compounds [38]. Moreover, the antimicrobial activity of Juniperus oxycedrus EO was 
found against $S$. aureus subs. aureus (CCM 4223) and predominant constituent of J. oxycedrus EO was also identified as $\alpha$-pinene [39]. In a study of the antifungal activity of P. pinaster bark, its ethanolic extract displayed high antifungal activity against Trametes versicolor and moderate antifungal activity against Coniophera puteana [40]. It was shown that limonene has antibacterial activities against S. aureus (gram-positive), Pseudomonas aeruginosa (gram-negative), and the yeast, C. neoformans [41]. The antibacterial activities of $P$. elliottii resin-oil against multidrug-resistant strains were evaluated using the minimum inhibitory concentration (MIC) method. The MIC varied between 25 and $100 \mu \mathrm{g} / \mathrm{mL}$, and the drug-resistant mutant of Staphylococcus epidermidis was more sensitive to the oils [42].

Table 3. The minimum inhibitory concentrations (MICs) of essential oils from different aerial parts of Pinus eldarica against three microorganisms using gentamicin as a positive control.

\begin{tabular}{ccccc}
\hline \multirow{2}{*}{ Microorganisms } & \multicolumn{4}{c}{ MIC * $(\mu \mathrm{g} / \mathbf{m L})$} \\
\cline { 2 - 5 } & Needles & Pollen & Bark & Gentamicin \\
\hline C. albicans & na & 1000 & 125 & 16 \\
E. coli & na & 225 & na & 16 \\
S. aureus & 125 & na & 125 & 16 \\
\hline & & na-no activity.
\end{tabular}

\section{Materials and Methods}

\subsection{Plant Material}

Pine needles, bark, and pollen were collected from the Tabriz district in Iran. The samples were collected in June 2018 and identified (No. 4036) by the Herbarium of the School of Pharmacy, Tabriz University of Medical Sciences. The specimens were air dried at room temperature, powdered, and stored in airtight bottles at $4{ }^{\circ} \mathrm{C}$.

\subsection{Essential Oil Preparation}

P. eldarica bark, needles, and pollen powders ( $100 \mathrm{~g}$ ) were hydro-distilled (with $1.2 \mathrm{~L}$ of water) in a Clevenger-type apparatus by recirculating the condensed water. The distillation was terminated after $240 \mathrm{~min}$. The resulting EOs were dissolved in diethyl ether, collected, and treated with anhydrous sodium sulfate to remove excess water. The diethyl ether was removed carefully at room temperature, and the remaining EOs were stored in sealed vials at $4{ }^{\circ} \mathrm{C}$ until analysis.

\subsection{Gas Chromatography Mass Spectrometry (GC/MS) Analysis of the Essential Oils}

Analysis of the EOs was carried out using a Shimadzu QP5050A GC/MS instrument (Shimadzu, Kyoto, Japan) at the following conditions: the volume of sample injected was $1 \mu \mathrm{L}$; the helium carrier gas flow rate was $1.3 \mathrm{~mL} / \mathrm{min}$, with a split ratio $1: 8$; the injection site temperature was $270{ }^{\circ} \mathrm{C}$; a DB-1 capillary column $(60 \mathrm{~m} \times 0.25 \mathrm{~mm})$ was used, with a film thickness of $0.25 \mu \mathrm{m}$; the column temperature was $50{ }^{\circ} \mathrm{C}$ increasing at $4{ }^{\circ} \mathrm{C} / \mathrm{min}$ to $300{ }^{\circ} \mathrm{C}$; an ionization potential of $70 \mathrm{eV}$ was used; the source temperature was $300^{\circ} \mathrm{C}$; and the mass range was $30-600 \mathrm{~m} / \mathrm{z}$.

\subsection{Identification of Components}

The identification of the components was conducted using computer matching against library spectra (Library Database Wiley 229, NIST 21, NIST 107), obtaining their retention indices with reference to an n-alkane series (C8-C20) in a temperature-programmed run, interpreting their fragmentation pattern, and comparing the mass spectra with relevant reference samples and the literature $[43,44]$. 


\subsection{Microbial Strains and Culture Media}

All microbial strains were obtained from the Microbiology Laboratory, Drug Applied Research Center, Tabriz University (Tabriz, Iran) of Medical Sciences. Stock cultures of gram-positive S. aureus (ATCC 29213), gram-negative E. coli (ATCC 25922), and C. albicans (ATCC 10231) were sub-cultured and maintained on nutrient agar at $37{ }^{\circ} \mathrm{C}$ for $24 \mathrm{~h}$; subsequently, they were diluted in sterile saline solution $(0.85 \% w / v)$ to reach a final concentration of 0.5 McFarland $\left(\sim 1.5 \times 10^{8}\right.$ colony-forming units $[\mathrm{CFUs}] / \mathrm{mL})$.

\subsection{Determination of the Minimum Inhibitory Concentration}

Briefly, the EOs were dissolved in dimethyl sulfoxide and $180 \mu \mathrm{L}$ was serially diluted from $2000 \mu \mathrm{g} / \mathrm{mL}$ to $10 \mu \mathrm{g} / \mathrm{mL}$ (up to eight dilutions) in Mueller-Hinton broth (Merck KGaA, Darmstadt, Germany). These dilutions were added to 96-well microplates, and $20 \mu \mathrm{L}$ of the microbial cultures were added at a concentration of $1.5 \times 10^{8} \mathrm{CFU} / \mathrm{mL}$ to reach a final volume of $200 \mu \mathrm{L} /$ well. Gentamicin was used as the positive control as it is a broad-spectrum antibiotic, and normal saline/dimethyl sulfoxide (DMSO) was used as the negative control. To complete the test, each organism was suspended separately in $200 \mu \mathrm{L}$ of Mueller-Hinton broth. C. albicans (ATCC 10231) was cultured in Mueller-Hinton agar supplemented with $1 \%$ glucose. All the tests were performed in triplicate to ensure reliability of the results. The sealed microplates were mixed on a plate shaker at $300 \mathrm{rpm}$ for $30 \mathrm{~s}$. They were then incubated at $37^{\circ} \mathrm{C}$ for $24 \mathrm{~h}$ and observed for growth or turbidity; subsequently, the MIC was determined. The MIC was defined as the lowest concentration of the EO that inhibited the visible growth of a microorganism after overnight incubation [45]. For each well showing no growth, a loopful of broth was then sub-cultured on a nutrient agar plate (Merck KGaA, Darmstadt, Germany) to verify if the growth of the microorganism had been inhibited. The growth of the microorganism on the solid media indicated that the specific concentration of the EO was unable to inhibit the growth of the microorganism.

\section{Conclusions}

This is the first study, to our knowledge, that investigated the chemical composition and antimicrobial activity of EOs from the aerial parts of P. eldarica grown in northwestern Iran. The main components of the EOs were sesquiterpene hydrocarbons in the needles and monoterpene hydrocarbons in the pollen and bark. In particular, $\beta$-pinene, $\beta$-myrcene, limonene, and caryophyllene were the most abundant chemicals identified in the EOs of all three plant parts. The EOs demonstrated antimicrobial activity against some highly susceptible strains, E. coli, C. albicans, and S. aureus. The results of the study provide experimental evidence that EOs from aerial parts of $P$. eldarica can be useful in the EO industry and in the development of antibiotics. In addition, P. eldarica, which is widely grown in Iran, can be used to provide low-cost therapies in land surrounding the Caspian Sea.

Supplementary Materials: Gas chromatograms from the GC/MS analysis are available free of charge on the Internet.

Author Contributions: T.G., H.H., and K.H.K. designed the experiments. T.G. performed the experiments. H.S.K analyzed the antimicrobial data. S.A., S.F., and A.D. analyzed the phytochemical data. T.G., S.C.B., H.H., and K.H.K. wrote the main manuscript text, including all figures. All authors reviewed the manuscript.

Funding: This study was financed by the Drug Applied Research Center, Tabriz University of Medical Science, Tabriz, Iran (Grant No. 58972) and the Iran National Science Foundation (Grant No. 97008952). This work was supported by the National Research Foundation of Korea (NRF) grant funded by the Korean government (MSIT) (2018R1A2B2006879).

Conflicts of Interest: The authors have no conflicts of interest to declare.

\section{References}

1. Parsa, A. Flora of Iran; Offset Press Inc.: Tehran, Iran, 1978; Volume 1, p. 488. 
2. Afsharypuor, S.; Sanaty, F. Essential oil constituents of leaves and fruits of Pinus eldarica Medw. J. Essent. Oil Res. 2005, 17, 327-328. [CrossRef]

3. Ludwiczuk, A.; Skalicka-Wo'zniak, K.; Georgiev, M.I. Pharmacognosy: Fundamentals, Applications and Strategies; Badal, S., Delgoda, R., Eds.; Elsevier Inc.: Amsterdam, Netherlands, 2017; pp. 233-266.

4. Mamedov, N.; Craker, L.E. Medicinal plants used for the treatment of bronchial asthma in Russia and Central Asia. J. Herbs Spices Med. Plants 2011, 8, 91-117. [CrossRef]

5. Mamedov, N.; Gardner, Z.; Craker, L.E. Medicinal plants used in Russia and Central Asia for the treatment of selected skin conditions. J. Herbs Spices Med. Plants 2005, 11, 191-222. [CrossRef]

6. Chudnyi, A.V.; Rudenko, B.A. Composition of turpentine oil from Pinus eldarica Medw. Rastit. Resur. 1982, 18, $252-255$.

7. Irvani, S.; Zolfaghari, B. Phytochemical analysis of Pinus eldarica bark. Res. Pharm. Sci. 2014, 9, $243-250$.

8. Judzentiene, A.; Kupcinskiene, E. Chemical composition on essential oils from needles of Pinus sylvestris L. Grown in Northern Lithuania. J. Essent. Oil Res. 2008, 20, 26-29. [CrossRef]

9. Lee, J.H.; Yang, H.Y.; Lee, H.S.; Hong, S.K. Chemical composition and antimicrobial activity of essential oil from cones of Pinus koraiensis. J. Microbiol. Biotechnol. 2008, 18, 497-502. [PubMed]

10. Leite, A.M.; Lima, E.O.; Souza, E.L.; Diniz, M.F.F.M.; Trajano, V.N.; Medeiros, I.A. Inhibitory effect of $\beta$-pinene, $\alpha$-pinene and eugenol on the growth of potential infectious endocarditis causing Gram-positive bacteria. Braz. J. Pharm. Sci. 2007, 43, 121-126. [CrossRef]

11. De Sousa Eduardo, L.; Farias, T.C.; Ferreira, S.B.; Ferreira, P.B.; Lima, Z.N.; Ferreira, S.B. Antibacterial activity and time-kill kinetics of positive enantiomer of $\alpha$-pinene against strains of Staphylococcus aureus and Escherichia coli. Curr. Top. Med. Chem. 2018, 18, 917-924. [CrossRef]

12. Yang, V.W.; Clausen, C.A. Antifungal effect of essential oils on southern yellow pine. Int. Biodeter. Biodegr. 2007, 59, 302-306. [CrossRef]

13. Kokalisburelle, N.; Rodriguezkabana, R. Effects of pine bark extracts and pine bark powder on fungal pathogens, soil enzyme activity, and microbial populations. Biol. Control 1994, 4, 269-276. [CrossRef]

14. Kurose, K.; Okamura, D.; Yatagai, M. Composition of the essential oils from the leaves of nine Pinus species and the cones of three of Pinus species. Flavour Fragr. J. 2007, 22, 10-20. [CrossRef]

15. Sarvmeili, N.; Jafarian-Dehkordi, A.; Zolfaghari, B. Cytotoxic effects of Pinus eldarica essential oil and extracts on HeLa and MCF-7 cell lines. Res. Pharm. Sci. 2016, 11, 476-483. [PubMed]

16. Essien, E.E.; Newby, J.M.; Walker, T.M.; Ogunwande, I.A.; Setzer, W.N.; Ekundayo, O. Essential oil constituents, anticancer and antimicrobial activity of Ficus mucoso and Casuarina equisetifolia leaves. Am. J. Essent. Oils Nat. Prod. 2016, 4, 1-6.

17. Shafagha, A.; Shafaghatlonbar, M. Antimicrobial activity and chemical constituents of the essential oils from flower, leaf and stem of Gypsophila bicolor from Iran. Nat. Prod. Commun. 2011, 6, 275-276. [PubMed]

18. Ramalho, T.R.; Oliveira, M.T.; Lima, A.L.; Bezerra-Santos, C.R.; Piuvezam, M.R. Gamma-terpinene modulates acute inflammatory response in mice. Planta Med. 2015, 81, 1248-1254. [CrossRef] [PubMed]

19. Venskutonis, P.R.; Vyskupaityte, K.; Plausinaitis, R. Composition of essential oils of Pinus sylvestris L. from different localities of Lithuania. J. Essent. Oil Res. 2000, 12, 559-565. [CrossRef]

20. Benabdelkader, T.; Zitouni, A.; Guitton, Y.; Jullien, F.; Maitre, D.; Casabianca, H.; Legendre, L.; Kameli, A. Essential oils from wild populations of Algerian Lavandula stoechas L.: Composition, chemical variability, and in vitro biological properties. Chem. Biodivers. 2011, 8, 937-953. [CrossRef]

21. Kiran, C.R.; Chakka, A.K.; Amma, K.P.; Menon, A.N.; Kumar, M.M.; Venugopalan, V.V. Influence of cultivar and maturity at harvest on the essential oil composition, oleoresin and [6]-gingerol contents in fresh ginger from northeast India. J. Agric. Food Chem. 2013, 61, 4145-4154. [CrossRef]

22. Kim, D.S.; Lee, H.J.; Jeon, Y.D.; Han, Y.H.; Kee, J.Y.; Kim, H.J.; Shin, H.J.; Kang, J.; Lee, B.S.; Kim, S.H.; et al. Alpha-pinene exhibits anti-inflammatory activity through the suppression of MAPKs and the NF- $\mathrm{B}$ pathway in mouse peritoneal macrophages. Am. J. Chin. Med. 2015, 43, 731-742. [CrossRef]

23. Rufino, A.T.; Ribeiro, M.; Judas, F.; Salgueiro, L.; Lopes, M.C.; Cavaleiro, C.; Mendes, A.F. Anti-inflammatory and chondroprotective activity of (+)- $\alpha$-pinene: Structural and enantiomeric selectivity. J. Nat. Prod. 2014, 77, $264-269$. [CrossRef] [PubMed]

24. Kovač, J.; Šimunović, K.; Wu, Z.; Klančnik, A.; Bucar, F.; Zhang, Q.; Možina, S.S. Antibiotic resistance modulation and modes of action of (-)- $\alpha$-pinene in Campylobacter jejuni. Plos ONE 2015, 10. [CrossRef] [PubMed] 
25. De Almeida Pinheiro, M.; Magalhães, R.M.; Torres, D.M.; Cavalcante, R.C.; Mota, F.S.; Oliveira Coelho, E.M.; Moreira, H.P.; Lima, G.C.; Ara\&\#xFAjo, P.C.; Cardoso, J.H.; et al. Gastroprotective effect of alpha-pinene and its correlation with antiulcerogenic activity of essential oils obtained from Hyptis species. Pharm. Mag. 2015, 11, 123-130.

26. Yu, L.; Yan, J.; Sun, Z. D-limonene exhibits anti-inflammatory and antioxidant properties in an ulcerative colitis rat model via regulation of iNOS, COX-2, PGE2 and ERK signaling pathways. Mol. Med. Rep. 2017, 15, 2339-2346. [CrossRef] [PubMed]

27. Crowell, P.L.; Gould, M.N. Chemoprevention and therapy of cancer by d-limonene. Crit. Rev. Oncog. 1994, 5, 1-22. [CrossRef] [PubMed]

28. Yang, D.; Michel, L.; Chaumont, J.P.; Millet-Clerc, J. Use of caryophyllene oxide as an antifungal agent in an in vitro experimental model of onychomycosis. Mycopathologia 1999, 148, 79-82. [CrossRef]

29. Fidyt, K.; Fiedorowicz, A.; Strządała, L.; Szumny, A. $\beta$-caryophyllene and $\beta$-caryophyllene oxide-natural compounds of anticancer and analgesic properties. Cancer Med. 2016, 5, 3007-3017. [CrossRef]

30. McGuinness, W.A.; Malachowa, N.; DeLeo, F.R. Vancomycin resistance in Staphylococcus aureus. Yale J. Biol. Med. 2017, 90, 269-281.

31. Chukwu, M.O.; Abia, A.L.K.; Ubomba-Jaswa, E.; Obi, L.C.; Dewar, J.B. Antibiotic resistance profile and clonality of E. coli isolated from water and paediatric stool samples in the north-west, province South Africa. J. Pure Appl. Microbiol. 2019, 13, 517-530. [CrossRef]

32. Guleria, S.; Tiku, A.K.; Koul, A.; Gupta, S.; Singh, G.; Razdan, V.K. Antioxidant and antimicrobial properties of the essential oil and extracts of Zanthoxylum alatum grown in north-western Himalaya. Sci. World J. 2013. [CrossRef]

33. Kalemba, D.; Kunicka, A. Antibacterial and antifungal properties of essential oils. Curr. Med. Chem. 2003, 10, 813-829. [CrossRef] [PubMed]

34. Hoai, N.T.; Duc, H.V.; Thao, D.T.; Orav, A.; Raal, A. Selectivity of Pinus sylvestris extract and essential oil to estrogen-insensitive breast cancer cells Pinus sylvestris against cancer cells. Pharm. Mag. 2015, 11, 290-295.

35. Rivas da Silva, A.C.; Lopes, P.M.; de Azevedo, M.M.; Costa, D.C.; Alviano, C.S.; Alviano, D.S. Biological activities of $\alpha$-pinene and $\beta$-pinene enantiomers. Molecules 2012, 17, 6305-6316. [CrossRef] [PubMed]

36. Scalas, D.; Mandras, N.; Roana, J.; Tardugno, R.; Cuffini, A.M.; Ghisetti, V.; Benvenuti, S.; Tullio, V. Use of Pinus sylvestris L. (Pinaceae), Origanum vulgare L. (Lamiaceae), and Thymus vulgaris L. (Lamiaceae) essential oils and their main components to enhance itraconazole activity against azole susceptible/not-susceptible Cryptococcus neoformans strains. Bmc Complement. Altern. Med. 2018, 18, 143. [CrossRef] [PubMed]

37. Mancarz, G.F.F.; Laba, L.C.; Morais Silva, T.A.; Pazzim, M.D.S.; de Souza, D.; Prado, M.R.M.; de Souza, L.M.; Nakashima, T.; Mello, R.G. Chemical composition and biological activity of Liquidambar styraciflua L. leaf essential oil. Ind. Crop. Prod. 2019, 138, 111446. [CrossRef]

38. Rezzoug, M.; Bakchiche, B.; Gherib, A.; Roberta, A.; Guido, F.; Kilinçarslan, Ö.; Mammadov, R.; Bardaweel, S.K. Chemical composition and bioactivity of essential oils and ethanolic extracts of Ocimum basilicum L. and Thymus algeriensis Boiss. \& Reut. from the Algerian Saharan Atlas. Bmc Complement. Altern. Med. 2019, 19. [CrossRef]

39. Semerdjieva, I.; Zheljazkov, V.D.; Radoukova, T.; Radanović, D.; Marković, T.; Dincheva, I.; Stoyanova, A.; Astatkie, T.; Kačániová, M. Essential oil yield, composition, bioactivity and leaf morphology of Juniperus oxycedrus L. from Bulgaria and Serbia. Biochem. Syst. Ecol. 2019, 84, 55-63. [CrossRef]

40. Özgenç, Ö.; Durmaz, S.; Yıldız, Ü.; Erişir, E. A comparison between some wood bark extracts: Antifungal activity. Kast. Univ. Orman Fak. Derg. 2017, 17, 502-508.

41. Van Vuuren, S.F.; Viljoen, A.M. Antimicrobial activity of limonene enantiomers and 1,8-cineole alone and in combination. Flavour. Fragr. J. 2007, 22, 540-544. [CrossRef]

42. Leandro, L.F.; Cardoso, M.J.; Silva, S.D.; Souza, M.G.; Veneziani, R.C.; Ambrosio, S.R.; Martins, C.H. Antibacterial activity of Pinus elliottii and its major compound, dehydroabietic acid, against multidrug-resistant strains. J. Med. Microbiol. 2014, 63, 1649-1653. [CrossRef]

43. Adams, R.P. Identification of essential oil components by gas chromatography / mass spectroscopy. J. Am. Soc. Mass Spectrom. 1997, 8, 671-672. 
44. Sandra, P.; Bicchi, C. Capillary Gas Chromatography in Essential Oil Analysis; Huethig-Verlag: New York, NY, USA, 1987; pp. 259-274.

45. Andrew, J.M. Determination of minimum inhibitory concentrations. J. Antimicrob. Chemother. 2001, 48, 5-16. [CrossRef] [PubMed]

Sample Availability: Samples of the compounds are not available from the authors.

(C) 2019 by the authors. Licensee MDPI, Basel, Switzerland. This article is an open access article distributed under the terms and conditions of the Creative Commons Attribution (CC BY) license (http://creativecommons.org/licenses/by/4.0/). 